\title{
Singing by and with heart: embodying Candomblé's sensuous knowledge through songs and dances in Berlin
}

Nina Graeff*

Freie Universität Berlin nina.graeff@fu-berlin.de

*Universidade Livre de Berlim, pesquisadora bolsista pós-doutoral em Antropologia da Educação.

Submetido em 07/06/2018, Aprovado em 18/11/2018 


\section{Resumo}

Através de etnografia realizada em Berlim e no Recôncavo da Bahia, minha pesquisa de doutorado buscou entender os processos subjetivos e transculturais da aprendizagem corporal (embodiment) de uma tradição oral, a religião do Candomblé, tendo como ponto de partida para a análise o meu próprio corpo. Este artigo apresenta alguns de seus resultados relacionados à transmissão de cantigas e danças na única casa de Candomblé da Alemanha. Apesar da distância do contexto cultural original, o pai de santo e outros mestres enfatizam o valor da aprendizagem prática, isto é, através do emprego intensivo do corpo, em contraponto à instrução verbal. Tal aprendizagem pressupões processos miméticos, envolvendo toda a dimensão subjetiva do aprender e, portanto, do conhecimento sensível adquirido. Busco demonstrar aqui como música e a dança atuam na incorporação da "essência emocional" (MERLEAU-PONTY, 1945) do Candomblé e dos orixás, ao passo que precisão técnica e compreensão intelectual e semântica de letras, gestos, ritmos e melodias, tornam-se secundárias. Afinal a religião em questão fundamenta-se na experiência e no compartilhar dessa essência tanto com a comunidade quanto com os orixás.

Palavras-chave: embodiment, Candomblé, música e dança afro-brasileira, conhecimento sensível, aprendizagem corporal.

\section{Abstract}

By means of ethnographic fieldwork in Berlin and Recôncavo da Bahia, my Ph.D. research sought to disclose transcultural and subjective processes involved in the embodiment of an orally transmitted tradition, the Afro-Brazilian religion of Candomblé, having my own body as a point of departure. This article presents some results regarding the transmission of ritual songs and dances at "Ilê Obá Sileké", Germany's only house for the practice of Candomblé. Despite the distance from the original cultural context, the priest and further masters emphasize the value of learning through practice - in other words, through body engagement rather than verbal communication and instruction. This implies mimetic processes envolving the whole subjective dimension of learning and, hence, of the sensuous knowledge acquired. I seek to demonstrate how singing and dancing enable the embodiment of the "emotional essence" (MERLEAU-PONTY, 1945) of Candomblé, whereas their intelectual and semantic understanding as well as their technical precision become secondary. For the primacy of the religion lies on the bodily experience and sharing of this very essence both with the community and with the gods, the orixás.

Keywords: embodiment, Candomblé, Afro-Brazilian music, sensuous knowledge, bodily learning. 


\section{Introduction}

How can a bodily ${ }^{1}$ transmitted tradition endure centuries of forced diaspora, slavery, persecution and prejudice? This question motivated my Ph.D. research on the transcultural $^{2}$ embodiment $^{3}$ of the Afro-Brazilian religion of Candomble in Berlin and Bahia (GRAEFF 2016). Knowledge can be partially stored in archives, written sources, recordings, etc., but it is assimilated and enacted by and within human bodies, especially in their interaction; in their "cultural performances" (KIRSHENBLATT-GIMBLETT, 1998; TAYLOR 2003, 2008). If bodies are mobile and therefore transcultural, diasporic cultural practices such as Candomblé are the very bodily realization of such paradigm.

In the beginning of my fieldwork in Berlin 4 , my aim was to learn songs and dance steps of the orixás ${ }^{5}$, Candomblé's deities, in order to observe mimetic processes (GEBAUER; WULF, 1992) in the assimilation of bodily knowledge. This inicital scope would enable me to describe the ways by which "body techniques" (MAUSS, 1950) and "practical knowledge" (BOURDIEU, 1972; 1980) are acquired. However, after some months undertaking participant participant observation (WACQUANT, 2000) informed by performative ethnography (FABIAN 1990; CONQUERGOOD 1991) in Germany's only Candomblé house, Ilê Obá Sileké ${ }^{6}$, my understanding shifted.

The apprenticeship embraced much more than memorizing lyrics and melodies; much more than obtaining the ability to execute specific mechanical techniques. Mimetic learning is mostly an unconscious undertaking that strives to the appropriation of and to the transformation through the other and the world ("Anverwandlung", GEBAUER; WULF, 1992), leading to the assimilation of expression forms with their values and meanings. I was embodying the experiences re-enacted by those techniques and, through them, the meanings and values of Candomblé. Unintentionally, my own experience became a paradigm for "transcultural embodiment": that mimetic process turned me into a Candomblé apprentice, an abian ${ }^{7}$.

\footnotetext{
1 As this article shall make clear, the transmission of bodily knowledge goes much beyond oral and verbal communication, engaging the body as a whole.

2 Transculturality, as coined by Welsch (1999), understands culture as the intersection of common experiences between individuals regardless of cultural contexts and backgrounds.

3 Embodiment is employed here especially in the sense of Csordas (1990) and Butler (1988). In Candomblé, the concept of "embodiment" has a further fundamental meaning, for most practitioners incorporate deities during trance states - Candomblé apprenticeship also involves learning to embody one's orixá.
}

$4 \quad$ The fieldwork in Berlin began in April 2013 and has never stopped, since I've become a member of the community. However, there was an "official" period of ethnographic fieldwork, in which data was systematically gathered in the field, that extended from end of July 2013 till mid-March 2014. My fieldwork in Bahia lasted from October 2014 until beginning of February 2015.

5 Orishas, in Portuguese orixás, are West-African deities praised in Candomblé as well as in Santería. I prefer to use, when possible, the Brazilian spelling for Candomblé terms.

6 The house was officially founded in 2008 by Babalorixá Muralesimbé and his spiritual leader lalorixá Mãe Beata de lemanjá. It is located in the famous neighborhood of Kreuzberg, in the middle of Berlin, sharing space with the intercultural center "Forum Brasil", managed by Babalorixá Muralesimbé and the German psychotherapist Martin Titzck. The religious community led by Babalorixá Muralesimbé has existed, however, for more than sixteen years.

7 Yoruba word for Candomblé members still not initiated. So far, I have only gone through obori, a ritual that afilliates a person to the religion and to a community. Further details are part of Candomblé's secrecy. 
Mimetic processes occur mostly at the unconscious level, conveying the impression that one didn't undergo learning processes. Only when looking back to the past, one might become aware of them. Until then, mimesis remains mostly "secret", hidden from one's awareness:

While an individual is acting, he is not aware of the mimetic aspect of his action; this remains hidden. Neither scientific thought pays attention to mimesis, since it chooses the path of conceptual construction. (GEBAUER; WULF, 1992, p. 35. Trans. by author)

Towards a more sensitive and broader understanding of mimesis and of Candomblé, my research strived to merge scientific with religious concepts by connecting their points of intersection. My intention was not to present Candomblé from an outer perspective of "a knowledge subject that would present the native theory as an object", but rather to "try out another relationship with native discourse and practices, their possibilities of emergence within the academic space." (ANJOS, 2008, p. 78, trans. by author) In that sense, the very idea of mimesis and of tacit learning seemed to correspond to the power assigned to the orixá Ossaim.

While all orixás have their own sacred leaves, Ossaim is the only one to know their secret. One may "know about" (RYLE, 2009) leaves, that is, comprehend and identify their names and biological functions for instance, however, one can only "know how" (id.) to cultivate and employ them through experience. Ossaim holds the secret of the leaves, because he is the one to harvest them (cf. COSSARD, 2008, p. 45) and to have direct experience with living herbs of the forest. The "know how", thus, equals the "secret" knowledge acquired unconsciously through practice. One may grow a collection of "leaves", "representations", "books" or memorize an entire encyclopedia, without grasping the essence, secret and power behind them. As Walter Ong's "dead" words (2002, p. $32)$, if the leaves are not used, acted, transmitted and cultivated, they will dry out and die:

The fact that oral peoples commonly and in all likelihood universally consider words to have magical potency is clearly tied in, at least unconsciously, with their sense of the word as necessarily spoken, sounded, and hence power-driven. (ONG, 2002, p. 32)

This article seeks to demonstrate the "magical potency" behind sounds being sung and gestures being danced in rituals. It shall unfold the bodily and, hence, subjective and sensuous dimension of the "production of symbolic worlds" in the religion:

The concept of mimesis implies resistance against the division of the human dimensions of experience, action and of the production of symbolic worlds in a theoretical and a practical side. It opposes such a segmentation, which appears

\footnotetext{
8 "Trata-se aqui de não fazer uma exposição desde fora, do lugar de um sujeito de conhecimento que apresentaria um pensamento nativo, enquanto objeto. (...) Trata-se de experimentar uma outra relação com o discurso e práticas nativas, suas possibilidades de emergência no espaço acadêmico."
} 
to be so definite, that makes any attempt to communicate it seems useless. ${ }^{9}$ (GEBAUER; WULF, 1992, p.11. Trans. by author).

The intensive engagement of the body in Candomble dissolves the constructed separation between theory and practice, objectivation and subjectivity, world and self. "My body has its world, or understands its world, without having to make use of my 'symbolic' or 'objectifying function'" (MERLEAU-PONTY, 2005, p. 162). Such dimensions of bodily learning often escape academic writing for reaching beyond conceptual constructions and verbal representations.

Towards filling this gap, instead of scrutinizing Candomble melodies and dance gestures as autonomous objects, in this paper I account for their apprenticeship as one fundamental dimension of the ineffable sensuous knowledge that is shared and embodied in the collective ritual practices ${ }^{10}$. After having contextualized the Candomble community of Berlin and its modes of transmission in two earlier publications (GRAEFF 2014a; 2014b), this article will focus on the gradual process of developing such knowledge, which, as in Ingold's "sentient ecology",

"is knowledge not of a formal, authorised kind, transmissible in contexts outside those of its practical application. On the contrary, it is based in feeling, consisting in the skills, sensitivities and orientations that have developed through long experience of conducting one's life in a particular environment". (INGOLD, 2002, p. 25)

Therefore, to pursue Candomblés "practical logic" (BOURDIEU, 1980) as closely as possible, I have intentionally refrained from learning about Candomble through academic sources, choosing to learn it as most practitioners in Berlin: by frequenting the house, eventually getting information on the internet, reading orixás myths, as well as exchanging with other members. Furthermore, since newcomers do not receive any theoretical introduction to the religion, I do not consider a general contextualization of Candomble as a necessary background for the reader to grasp the proposed discussion ${ }^{11}$. Instead of introducing abstractly and linearly the several historic, sociocultural and structural aspects of the religion ${ }^{12}$ and of the community members, they are approached situatively (LAVE; WENGER, 1991), according to the requirements of the ongoing arguments. As my fieldwork would demonstrate, in Candomblé answers come with time, through what is called catar folhas ("collect leaves", see for instance GOLDMAN, 2005, and COSSARD, 2008).

$9 \quad$ "Der Mimesisbegriff beinhaltet Wider-stand gegen die Spaltung der menschlichen Bereiche der Erfahrung, des Handelns und des Erzeugens symbolischer Welten in einen Praxis- und einen Theorieteil; er wendet sich gegen eine Aufgliederung, die so end $\neg$ gültig aussieht, daß jede Vermittlung sinnlos zu sein scheint."

10 Instead of separating scientific or intellectual knowledge from practical or sensuous knowledge, my aim is to emphasize the second as a fundamental dimension of knowledge production and analysis.

11 This methodological choice is also a political position that aims to balance the asymmetric relationship between scientific and non-scientific knowledge (SANTOS 2007), or, as proposed by performance studies, between academic and practical knowledge (e.g. CONQUERGOOD 2002).

12 The bibliography about Candomblé is very broad, having Nina Rodrigues (1900) and Roger Bastide (1958; 1960) as its first important exponents. The reader may find a comprehensive and critical literature review of the religion in Goldman 2009. 
Most of the cantigas learned in Berlin are in Yoruba language ${ }^{13}$, so that their exact phonemes and literal content remain mostly unknown among the community members $^{14}$. Consequently, literal meanings and formal precision become not as important as the ability to collectively sing cantigas "by heart", and hence to experience them within one's own body during rituals, as the first section of this paper reveals. Since in Candomblé "dancing is listening"15 and vice-versa, this inextricability will also be explored as an important dimension of embodying the emotional essence of the orixás in the second section. The last section shows that by experiencing the same cantigas in different contexts, one starts to embody their contextual meanings and their functions, beginning to sing them "with heart": with the emotions evoked and embodied along several experiences and contexts.

\section{Learning "by heart"}

"Sing what your heart says, not what your reason says"16 Babalorixá Muralesimbé, Candomblé spiritual leader in Berlin

What does "to learn by heart" mean? Is it simply to memorize information, to be able to reproduce it anytime and anywhere? This widespread expression ${ }^{17}$ alludes to embodying a knowledge till the point that reproducing it dispenses with intellectual reflection. It becomes part of one's body, transforming and enriching it - and knowledge itself - at each new reproduction. Babalorixá Muralsimbé's ${ }^{18}$ above sentence opposes heart and reason, but not for asserting a dichotomy between emotions and rationality or between body and mind. Instead, he is stating a Candomblé value, which this article will evoke.

\footnotetext{
13 Ilê Obá Sileké is a candomblé house from the kétu tradition, being more oriented towards Yoruba culture. However, as most Candomblé houses, it also practices songs in Ewe, Fon and Bantu language, as well as cantigas de caboclo in Portuguese. Communication among frequenters takes place mainly in Portuguese and German, but also eventually in English, Spanish and French.
}

14 This is also valid for the melodic inflexions of the tonal language, which are implicit in the chants' melodies but only rarely approached in the community, having no relevance for the discussion proposed in this paper.

15 "Zu tanzen ist zu hören", frequent statement of masters during orixás' dance classes.

16 "Sing was dein Herz sagt erstmals, nicht was dein Verstand sagt", Babalorixá Muralesimbé during recorded cantigas class on 03.03.2014.

17 Found also in Portuguese "saber de cor" and "decorar", as well as in French "apprendre par coeur".

18 Babalorixá is the male Candomblé priest. Babalorixá Muralesimbé (50+), also known under his artistic name Murah Soares, is a professional dancer from Salvador da Bahia, who moved to Berlin in 1989. He is the founder and cultural manager of the German-Brazilian intercultural center Forum Brasil in Berlin, which accommodates the Candomblé community. Murah was born and raised dentro do Candomblé ("within Candomblë"), as practitioners say, by his Kenyan grandmother. At the age of eighteen, he was initiated by Badu d'Oxóssi, filho de santo (initiate) of Mãe Senhora from the traditional Candomblé house Ilê Axé Opô Afonjá. After Badu d'Óxossi diceased, Murah became filho de santo of Mãe Beata de lemonjá, who was filha de santo of Olga do Alaketu, from the traditional Terreiro do Alaketu. 
In the first months of my fieldwork in Berlin, the community members ${ }^{19}$ had the opportunity of taking "cantigas classes" with the recently arrived Ogã ${ }^{20}$ Paulo d'Ogum ${ }^{21}$. Once during a cantiga class, Babalorixá Muralesimbé mentioned an example from his childhood for commenting on "the path" of learning cantigas, based on his own path. He had once memorized a cantiga in Yoruba mixing it up with Portuguese words. The mistake, however, didn't matter:

\begin{abstract}
Muralesimbé: When I was a child, I also learned. Children learn whatsoever and everything is Portuguese for them, you know? When I was a child, for instance... "Alakoro eleun o" - for me, being a kid, I thought "[Alakoro] ele é um" (he is one), for me in my head it was like this. It has nothing to do do [with the Yoruba meaning], it's not about "he is one". It has nothing to do with Portuguese but, still, for me it was Portuguese [sings]. Until my father came and explained it to me. But I could already sing the melody, the song, so I could immediately switch it [the phonemes]. That's how it is.

Iris d'Ossaim ${ }^{22}$ : I sing often nonsense!

M: That's better: sing what your heart says first, not what your reason says... And later will you always, how do you say? Polish, sharpen it... That's the path, that's how l've learned it. There are some things that other people learned in different ways, but that's how I've learned it and for me it was pretty easy. [...] Once everyone can sing everything, we will sit down and correct it, but first the melody must be in the head ${ }^{23}$. (Recorded cantigas class on 03.03.2014)
\end{abstract}

For Murah, it's "better" to sing "nonsense" in the first instance of memorizing cantigas. One must first incorporate the "melody, the song", without reflecting on the lyrics' correctness and meanings. First the music "must be in the head", or "in the heart"; it must get internalized in one's body to the extent that the learner will be able to carry, that is, to reproduce it anywhere.

The ability to reproduce a skill anywhere, and independently of further knowledge transmitters, implies improving and enriching the skill at each performance. Each time one perceives a song differently; each time one executes it, more information will one gather, being able to correct, "polish" and sharpen it ${ }^{24}$.

\footnotetext{
19 The description of members only concerns the aspects generally gathered at first instance in practice: gender, approximate age and provenience.
}

20 Ogãs are male Candomblé members with special functions, among them the mastering of drums and songs.

21 Brazilian musician from Salvador, 30+.

22 German woman, 40+

23 "Muralesimbé: Ich habe als Kind auch gelernt, Kinder lernen irgendwas, sie lernen irgendwas und alles ist auf Portugiesich, weisst du? Als ich Kind war, zum Beispiel [...] "Alakoro eleun o" Für mich als Kind, ich habe gedacht "[Alakoro] ele é um [er ist ein]", für mich war in meinem Kopf so, es hat nichts damit [mit der Yoruba Bedeutung] zu tun, nicht "ele é um". Hat nichts mit Portugiesisch zu tun und für mich war es Portugiesisch [Murah singt]. Bis mein [spiritueller] Vater gekommen ist, dann hat er [es] mir erklärt. Aber die Melodie, den Gesang, hatte ich schon und dann: [habe ich es] sofort umgesetzt. Es ist so. - Iris: Ich singe häufig Quatsch! - M: Es ist besser: sing was dein Herz sagt erstmals, nicht was dein Verstand sagt... Und danach wird man immer, wie sagt man das? "Lapidar"? schleifen, polieren... Das ist der Weg, so habe ich gelernt. Es gibt Sachen die andere Leute anders gelernt haben, aber ich habe so gelernt und für mich war es ganz einfach. [...] Quando todo mundo souber cantar tudo, aí a gente vai sentar e corrigir, mas primeiro a melodia tem que estar na cabeça."

24 My learning of a cantiga de oxalá song "oni sá wure" exemplifies this. When a member mentioned this song in his interview as being one of his favourites, I didn't know it and asked him if it was for Xangô, his orixá. I surely had heard it two months earlier during our ritual for Oxalá; however, only in Bahia I started to recognise and embody it, improving the lyrics at each new performance mentioned. During our Oxalá's ritual in January 2016, I still added new information, "polishing" the song once more into Babá's form. Three weeks later, we chanted it again and I could 
In the case of singing, "to have the music" within one's body is not restricted to intellectually memorizing its melody, but implies the embodiment of its ineffable wholeness, which only becomes possible through bodily practice. This coincides with the frequent claims in ilê against rationalization while singing and dancing:

\begin{abstract}
Verinha came and we first presented our "homework". She recalled most of the songs very well, but needed some impulse from Paulo in order to begin. Then she would miss the lyric (bois-três, rês um-três) and Paulo went on, saying "in music one must sing. If one thinks, it gets blocked. One is not supposed to think". (Field note from 14.10.2013)
\end{abstract}

The fact that Vera d'Oxum ${ }^{25}$ could remember "most of the songs" as soon as Paulo sang their beginnings, concerned solely the melodies. Despite singing in her own language, she was still struggling with the lyrics, which in this example have a very explicit, both poetic and mathematical, logic:

Na minha boiada me falta um boi, oh me falta um, oh me faltam dois Na minha boiada me falta um rês, oh me falta um, oh me faltam três

My herd lacks an ox, oh it lacks one, oh it lacks two

My herd lacks a cattle, oh it lacks one, oh it lacks three

Still, Paulo remarks prioritize that Vera simply sings, practices the song, instead of intellectualizing it, while trying to remember the right words and their explicit logic. He was referring not so much to Vera's attempt to grasp the lyrics' logic, but to the preoccupation of singing them correctly. Babalorixá Muralesimbé expresses in manifold ways and contexts the idea that "thinking" during practice is connected to doubt and fear of making mistakes, which causes a "block". This was precisely the first answer Dofono João de Xangô ${ }^{26}$ gave to my question on the reasons for the difficulties in learning cantigas: "I think there is a rationalization block"27. Conflicting emotions such as confusion and fear result in what Csikszentmihalyi (1988) calls "psychic entropy", which "not only causes disorder in consciousness, but impairs its efficiency as well. Attention is withdrawn from other tasks to deal with the conflicting information" (p. 22).

Once again, Ogã Paulo, Muralesimbé and João are not separating mind and body, reason and intuition. They are also not attesting that when singing, one does not "think" or "rationalize", instead they are reiterating the centrality of practice and experience in Candomblé, which in the case of music is highly evident, as Merleau-Ponty illustrates with the example of listening to a sonata:

\footnotetext{
sing along the same text he was calling. Hence, I had first to "have the melody" in my body, carrying it between Berlin and Bahia, to gradually sharpen both my perception and execution at each performance.

25 Brazilian woman from Rio de Janeiro, 60+.

26 Brazilian man from Campinas, 40+, Candomblé initiate since 2012.

27 Interview on 27.02.2014, Berlin.
} 
The musical meaning of a sonata is inseparable from the sounds which are its vehicle: before we have heard it no analysis enables us to anticipate it; once the performance is over, we shall, in our intellectual analyses of the music, be unable to do anything but carry ourselves back to the moment of experiencing it. During the performance, the notes are not only the 'signs' of the sonata, but it is there through them, it enters into them. (MERLEAU-PONTY, 2005, p. 212)

Accordingly, to learn and practice a song does not necessarily mean to understand its lyrics, to list down or transcribe its objective features and its signs, but to "be through" those sounds and meanings by sensing them, with and within the body. Music only acquires significance when heard, sensed by means of its sounds. This very idea I embodied through time, unconsciously but also consciously, as when Ogã Paulo told us to "sing with our bodies":

\begin{abstract}
Verinha had difficulty in reading/writing, but later she mastered well the cantigas. She would sing with the body, as Paulo demanded, because he said that we want to think, to understand, but it's with the body that one understands them. I'd try to understand the rhythms and memorize the lyrics [...] then I'd try to "embody", to feel it with the body. [...] Later Paulo talked about the importance of learning the cantigas, because of the house too, but especially for the orixás. ${ }^{28}$ (Cantigas class on 28.10.2013)
\end{abstract}

Despite of the tautology in "singing with the body", it does make a difference to free the body from rational thoughts, to close one's eyes and simply concentrate on the feeling of the song. I did not stop thinking while doing it; I rather shifted to a "somatic mode of attention", as coined by Csordas:

Because attention implies both sensory engagement and an object, we must emphasize that our working definition refers both to attending "with" and attending "to" the body. To a certain extent it must be both. To attend to a bodily sensation is not to attend to the body as an isolated object, but to attend to the body's situation in the world. The sensation engages something in the world because the body is "always already in the world." Attention to a bodily sensation can thus become a mode of attending to the intersubjective milieu that give rise to that sensation. Thus, one is paying attention with one's body. (CSORDAS, 1993:138)

The shift went from thinking about the song, about its lyrics, its melodic movements, and from my concern on hitting the "right notes", to its bodily sensations and feeling the song. When stating one should not try to "understand" the song, Ogã Paulo meant to intelectually understand it by means of critical reflection and judgment. One should instead "understand with the body"; understand the song by feeling it, since "to feel the world is another way of thinking it, of transforming it by turning the sensuous

\footnotetext{
28 "Verinha [...] tinha dificuldade de ler/escrever, mas depois pegou bem as cantigas, cantava com o corpo, como o Paulo pediu, pois disse que queremos pensar, entendê-las, mas a gente entende é com o corpo. Eu tentava entender ritmo e decorar a letra [...] e aí tentava 'incorporá-la', senti-la com o corpo. Para mim o pior é a letra... Depois Paulo falou como é importante aprender as cantigas, muito para a casa também, mas especialmente pros orixás".
} 
intelligible"29 (BRETON, 2007, p. 53. Trans. by author). Similarly, "to sing with the body" transforms gradually what is sensed, i.e. the sounds, into an intelligible song - even if one ignores its literal meanings.

Furthermore, "singing with the body" shifts the attention to the resonance of the music within one's own body, to the sensation of its "incorporation" as well as its resonance with the voices of others. By singing the same tones, when the voices are similarly aligned, a profound resonance is collectively felt:

The one who participates at choir singing experiences in the successful moments feels a "deep resonance" first between his body and his mental state, secondly between himself and the other singers, and third the formation of a physically and collectively shared space of resonance (in the church, the concert hall, etc.). ${ }^{30}$ (ROSA, 2016 p. 111-112. Trans. by author)

Conversely, the mistaken intonation of a song might corrupt this collectively shared space of resonance, so that one seeks to restore it. One seeks to "tune" himself to others, as I wrote about a praying moment before an lemanjá's festivity:

To my left was Madalena d'lemanjáa ${ }^{31}$ and to my right Emerson d'Ogum ${ }^{32}$. I didn't know if I was the one mimetizing him or the opposite. I'd try to repeat what I heard from the camarinha [the room where masters were calling the songs] and "tune" it with him. But his lyrics also varied; he seemed insecure about them. (Field note from 08.02.2014)

Since I had not seen Emerson in ilê many times, I ignored his background, and since he was singing most of the songs, I supposed that he was conversant with cantigas and I relied on him for imitating the lyrics. Once I noticed him varying and demonstrating insecurity about them, I wondered who among us was imitating whom, for I was also varying the lyrics. Later I would find out that he was also a newcomer in Candomblé, who started to frequent ilê one year before me, although irregularly. We were both mimicking one another to seek consonance; to "tune" our singing one to another and to the environment, i.e. with what we heard from the masters' room.

As Paulo reminded us during a class, to learn cantigas is important for the house - in order to make the rituals sound, that is, resonate more beautifully among the community and thereby produce more axé, Candomblé's vital energy. However, to memorize the songs is first and foremost important for the veneration of the orixás. Prior to any perfection claim is the willingness to communicate with the orixá, as the indigenous

\footnotetext{
29 "Sentir le monde est une autre manière de le penser, de le transformer de sensible en intelligible."

30 Wer sich daran [am Chorsingen] beteiligt, erfährt in den gelingenden Momenten eine "Tiefenresonanz" zwischen seinem Körper und seiner mentalen Befindlichkeit zum Ersten, zwischen sich un den Mitsingenden zum Zweiten sowie die Ausbildung eines kollektiv geteilten physischen Resonanzraums (in der Kirche oder Konzertsaal, etc.) zum Dritten.

31 Brazilian woman from Rio Grande do Sul, 50+

32 Brazilian man from São Paulo, 30+
} 
spirit Seu Ventania ${ }^{33}$ expressed once in September 2013: "one must know how to sing for calling the 'shpit' [spirit in pidgin Portuguese], for the shpit to enter their lives"34. My own embodiment of this ideal communal or spiritual singing led me to later sing for the orixás also alone and wherever I go, while feeling their resonance in my body as well as in my surroundings. While "sounding" for the orixás, we are resonating them: spreading their force into the world and into oneself.

However, the inability to resonate in this sense is also instructing. Because one's body is taken for granted, we tend not to perceive it: "the bodily movements are accompanied by sensations, but sensations to which we are normally inattentive; our attention is attracted when they go wrong" (CONNERTON, 1989:102). When this happens, one is compelled to enter a "somatic mode of attention", paying attention with and to the body. This became evident at my first lemanjá festival in February 2014:

\begin{abstract}
I was still a bit sick and soon my voice weakened, increasing my fatigue. When we prayed upstairs, I felt very unwell, dizzy, and noticed that my nose was half blocked and that I couldn't breath properly for singing. We repeated some of the songs several times. The house's lansã and Xangô were present [incorporated in the bodies of initiates]. Verinha cried; she even sat at some point. Amankwa ${ }^{35}$ had his shakings. I noticed the importance of responsorial chant, which makes intermittent breaks for those who are not singing at the moment. (Field note from 08.02.2014)
\end{abstract}

After years, I can still remember the feeling of my fatigue, of my breathing trouble as well as of the physical resistance required to sing repetitively in our uncomfortable praying position - the reason why I remarked that Vera abandoned it for sitting. Nowadays I also recognise the strong energy of the moment: Vera crying, Amankwa de Xangô shaking, the bodily presence of the two main orixás of the house - perhaps my body feeling was not exclusively linked to my health condition. To be constrained by my body condition made me aware of the communal principle of call and response singing: it presupposes a break for breathing ${ }^{36}$, depending essentially on social interaction. It made me understand both sensibly and intellectually the "importance of responsorial singing". Being sick made me aware of my body's functioning as well as its social function within the ritual.

Feeling resonance and consonance correspond to subjective aspects of singing. Even when conversant with a song, there are performance nuances one might ignore. For instance, the music speed also expresses the energy of each orixá and of each ritual moment. The tempo - a better term for a feeling than an objective, fixed speed such as

\footnotetext{
33 Caboclos, indigenous spirits are also common in Candomble houses, taking over the body of practitioners during trance states and, different from the orixás in trance, communicate verbally with preacitioners. Seu Ventania is the indigenous spirit incorporated by Babalorixá Muralesimbé.

34 "Tem que saber cantar para chamar 'pito'(?) [espírito]. Para o 'pito' entrar na vida deles".

35 German man, 20+.

36 Months later, I would enlarge this conception while singing Samba de Roda with Paraná at a Brazilian event in Berlin and not having any participants to respond my calling: I lost my voice and got exhausted very fast. This was when I also understood that Samba de Roda singing presupposes a participating community for performing both call and response, which means to achieve its complete communal dynamics.
} 
"100 beats per minute" - plays an important role on the expressiveness of a song and on its ritual context. Although tempo is implied in the performance of a song, its nuances might be explicitly corrected, as Babalorixá Muralesimbé did once after requesting Dofono João to call a reza in his place: "Babá corrected João sometimes - he was singing too fast - "slower! Like this... Now that's a reza [a sung prayer]!" (Field note from 09.10.2013)

Also during a cantigas class Ogã Paulo asked us to sing "relaxed" and to "not pull it forward"37. Such corrections do not relate to an objective speed of $100 \mathrm{bpm}$, for instance Ogã Paulo corrected our inadequate speed, a rushing one that "pulls the song forward", by telling us to sing "relaxed", which is to perform it with a different body feeling. Babalorixá's correction, in turn, alludes to a general, contextual, feeling related to performances of rezas, which he usually sings very slowly, calmly and solemnly.

Even after mastering the most "objective features" of several cantigas, I would learn another nuance, regarding their performance, the sotaque ("speech accent"). After complimenting my improvement, Ogã Paraná ${ }^{38}$ made some remarks on a song for the orixá Oxumarê we had executed at a dance workshop. We sang it together while he corrected me by turning my attention into his body movements:

\begin{abstract}
Paraná said that our sotaque was not good (alluding gesturally to a march); it was too "square". I sang "arroboboi o guele si" and he kept correcting me. Only when I bounced together with him I was able to detach from the time-line-pattern he was striking; the melody almost fluctuates - like Oxumarê. Later I sang "odé komorodé" [a song for Oxóssi] and he had nothing to remark. This song is indeed more "square", accentuating the beats. (Field note from 04.06.2014)
\end{abstract}

Ogã Paraná made a gestural metaphor for what we verbally refer to as a "square" rhythm. In our communication on the corrected feature, neither verbal metaphors nor gestures sufficed for referring to such a sensuous dimension. We sang together, as to make me "tune" to his sotaque, until I also "tuned" to his bouncing body, moving mine in the same manner. Only at that moment I could "untie myself from the time-line-pattern he was striking" and sensuously grasp what he meant. In musicological terms, the rhythm of my melody would no longer coincide so neatly with the strokes of the timeline-pattern ${ }^{39}$. It would, rather, "fluctuate" as Oxumarê, the orixá of movement, who is also a snake. Once my melody began do "fluctuate" as a snake along with my body, Paraná declared it as correct.

The difference between my performances lied on the in-between the notes, in regards to both the rhythm and the lyrics. Objectively, it concerned, on the one hand, to no longer stress and to smoothly link each syllable to another; on the other hand, it was about not singing each note straight together with the elementary pulses. While writing such "results" down, I kept singing the song in the attempt to render objective

\footnotetext{
37 "Entspannt" and "nicht nach vorne ziehen". Cantigas class on 03.03.2014.

38 Brazilian man from São Paulo, 60+.

39 For a review of rhythmic principles underlying Afro-brazilian music, see GRAEFF 2014c.
} 
and verbal song nuances that can only be felt by moving the body. The bodily feelings I could only grasp at that moment through my movements, permeate since then my perception of the orixá of movement, Oxumarê, as well as of cantigas in general. Such differences in sensed nuances and "feelings" regarding the manifold forms that the orixás take would become much more evident in dance, as well as the centrality of the body in their learning.

\section{"Dancing is listening": Dancing to hear, feel and learn the orixás}

Being filha de santo ("spiritual daughter") of a priest who is a professional dancer as Murah Soares ${ }^{40}$ brings the opportunity of learning not only how to execute the orixás' steps, but also to dance. Babalorixá Muralesimbé masters the complexity both of this art and of the orixá's symbology conveyed in dance movements. It is precisely their intricacy that he identifies as one of the most challenging dimensions of learning Candomblé in Berlin:

The dance alone has much information, the whole gesture of the dance, ok, let's say, it's not a choreography, but I will call it this way: its choreography tells an entire story; what the hand does, what the head does, when it goes to the floor, when one jumps, when one cuts, all these things. So it's very hard because there's much information inside a short dance, inside a short movement. ${ }^{41}$ (Interview with Babalorixá Muralesimbé on 03.03.2014).

This is one of the reasons leading Murah to offer public workshops on Candomble dances under the title "Die Kraft der Götter" ("The force of the gods") every Sunday after a public festivity. It is the occasion both for external audiences and for Candomblé members to learn ritual dances and their meanings. Conversely, his now extinct weekly classes on "Afro Brazilian Dance" was focused on movements, among which some "reminiscences" of the orixás steps and symbols were identifiable.

This dance practice would paradigmatically demonstrate how mimetic processes in Candomblé embrace much more than memorizing gestures. If "the human body has always served to produce and express similarities"42 (GEBAUER; WULF, 1992, p. 374. Trans. by author) and thereby to assimilate the world, dance is one of the most evident cultural activities in which such production and expression takes place. When dancing, one is not simply representing an image, if any, but being one with their whole body. While learning to dance for the orixás, expressing their gestures and symbols, one produces the deities: these might not only become present through trance, but their energy is both felt and expressed in the moving bodies of practitioners.

\footnotetext{
$40 \quad$ Artistic name of Babalorixá Muralesimbé.

41 "A dança em si já tem muita informação, o gestual da dança toda, tá, vamos dizer, não é uma coreografia, mas eu vou dizer assim, a coreografia dela, ela conta toda uma história, o que a mão faz o que que a cabeça faz, quando vai no chão, quando salta, quando corta, essas coisas todas, então é muito difícil porque é muita informação dentro de uma pequena dança, de um pequeno movimento só, é muita informação ali dentro."

42 "Schon immer dient der menschliche Körper dazu, Ähnlichkeiten her ᄀzustellen und auszudrücken."
} 
Likewise, the mimetic processes involved in dancing went much beyond the context of imitation and practice inside formal contexts of learning such as Murah's weekly classes and workshops. To gradually understand, memorize and develop a feeling for those body movements were entangled with the mimesis of rhythms, songs, myths, images of the orixás and of ritual structures, of which steps were only one modality. Different "modalities" 43 of one experience are embodied at the same time, as Bourdieu exemplifies with the memorization of poems "the rhythmic or metric demands are interiorized at the same time of the melody and the meaning, without ever being separately perceived"44. (BOURDIEU 1980, p. 126, trans. by author) Similarly, whether one is aware of it or not, dance movements, the music underlying them and the feelings conveyed are incorporated at once.

The inextricable interrelation between music and dance in African cultures is evident for several researchers (CHERNOFF, 1978; KUBIK, 1988). Just as words such as samba or toque designate simultaneously a type of music and of dance, the group performing it and the whole event, there are no terms in African native idioms for referring to music and dance separately from each other, as in Western thought (KUBIK, 1988). After all, music arises from movement and is constituted by motional patterns (KUBIK, 1983; PINTO, 1991), the same way that dance not only interacts with music, fostered by its sounds (HAZZARD-GORDON, 1983; DESMOND, 1993; WULF, 2007), but arises from it.

In order to embody this inextricable connection in a context such as Berlin, it is helpful however, to focus separately on each aspect and respective sense - dance and movement, music and listening. For this reason, Murah frequently calls our attention during the workshops to the toque do tambor, the percussion rhythms. Apart from the orienting role of the basic time-line-patterns given by the cowbell $g a$, the most important aspect to be attentive of while dancing are the signs given by the main drum, the rum. The field note from my first dance workshop describes Murah telling us to dance to the signs of the drum "as if it was something evident" 45 which is not the case of people not socialized in Candomblé. However, time and practice would render it evident.

In December 2013 I started to "gradually grasp the relation between [musical] rhythms and steps", becoming able to perceive how Xangô's rhythm fitted his basic dance step, Alujá de Xangô. Still, to respond to the drum calls with the respective step variations was not easy:

Several times, Murah would show the step variations, saying that one must listen to the drum playing. We trained the whole sequences paying attention to it. It didn't work very well. Besides being very difficult, since the sequences are not embodied, I didn't grasp the drum "call"; if there was any call, or if we were supposed to count till four and the "call" would start together with the variation...

\footnotetext{
43 Instead of separating different senses and expression forms, Merleau-Ponty regards them as "modalities and variations of the subject's total being" (MERLEAU-PONTY, 2005, p. 124), "modalities of existence" (p. 186), "modalities of being in the world" (p. 210).

$44 \quad$ "Les contraintes de rythme ou de métrique sont intériorisées en même temps que la mélodie et le sens sans jamais être perçues pour elles-mêmes."

$45 \quad$ Field note from 23.04.2013.
} 
At [the dance called] Avamunha it worked: the drummer would play the pattern once, we would wait, and then at the pattern's repetition we would start the variation. (Field note from 08.12.2013)

That was only the beginning of assimilating the rhythms and their interrelation to the dance steps. On the one hand, I still needed to embody the variations and, on the other, I couldn't "grasp the call" yet, that is, although hearing the pattern, I couldn't connect it to the dance movements. At that time, I was beginning to develop an overall knowledge of basic steps and toques - the ones we repeat and see the most - while for the variations both of the dances and of the drums, and by consequence their interrelation, I hadn't yet gathered enough experience for reproducing their bond.

The next ritual and dance workshop would represent an important step in this development. Until there, many cantigas classes had taken place and we had practiced several lemanjá's songs the weeks before. Consequently, at that lemanjá's festivity I "knew all the greetings, recognized what we sang, the rhythms and choreographies" 46 : such general knowledge was becoming "habitualized" (BOURDIEU 1972), "sedimented" in my body (cf. CONNERTON 1989), enabling me to perceive further aspects of the ritual and of the dances:

This time I perceived that every time we sang Avamunha was for the orixá to leave the room: Xangô, lansã, Oxum, lemanjá. At that moment they would enter the camarinha room. (Field note from 08.02.2014)

Avamunha's call was the one mentioned as seeming evident for Murah, but not for me. Nonetheless, time rendered it so evident to me that nowadays it even happens that I hear and react to it, preparing to change the dance step, even when Murah does not, for being concentrated on something else. After mastering the Avamunha song and basic step, I became able to perceive not only the call for variation automatically, without paying attention to it, but also further aspects of the rhythm. It has the ritual function of leading the orixás to the camarinha room while making them dance with the whole community - for Avamunha is the "communion dance".

\footnotetext{
"Dancing is listening". Ogã Paraná told us that at the age of three he began to learn and recognize the rhythms by dancing them and only later he learned how to play them (Murah didn't because he's not Ogã). Murah affirmed that they were both born and raised within Candomblé, learning it all since childhood. So that it is easy for them to hear the correlation, while for us it is not. He started showing Xangô's step slowly together with the rhythm, as if saying "now you pay attention..." Then he asked "do you understand what I mean?" - Actually we don't... (Field note from 09.02.2014)
}

Aware of our difficulties of "listening for dancing", Murah showed us a short and slowed down fragment of Xangô's dance with Ogã Paraná's accompaniment on the rum. He was confident about the efficacy of his demonstration towards making us un- 
derstand the interaction between the rum and the step. However, after demonstrating the step, he must acknowledge that no one had grasped it.

To illustrate, on the one hand, the importance of such interrelation and, on the other, its learning difficulty for people not socialized in Candomblé, Murah and Paraná told us about their own learning experiences during childhood. When they stated that because they were born and raised within the religion it is much easier for them than for newcomers to perceive the interrelation, they both recognized that "the world internalized in primary socialization is so much more firmly entrenched in consciousness than worlds internalized in secondary socializations" (BERGER \& LUCKMANN, 1967:134-135). Childhood - or primary socialization - may be regarded as a "sonorous bath" (BRETON 2006:122), for the child is immersed first in the sonorous universe of the mother's womb and later of the social world. Similarly, Murah and Paraná were very early immersed within the sonorous universe of Candomblé. Accordingly, if "the learning of sounds - the entrance into their familiarity through their integration into a universe of senses/ meanings - is part of the surrounding culture, of the sonorous bath, that impregnates the child"47 (BRETON, 2006, p. 122, trans. by author), those who were "born and raised in Candomblé" integrate its "sounds" and "senses" at once. Neither the senses nor the meanings they embody are separated from each other. Sound, body movement and meaning are strictly interwoven, and music and dance are only two modalities of one mimetic process.

While recognizing such interweaveness concerning West African traditional life, Agawu identifies a "larger scheme of rhythmic expression" (1987, p. 402) that integrates all its communication forms, from which music and dance arise. Rhythm is the ultimate link between music and dance; both are organized through temporal distances between strokes, notes, steps and gestures. Although one might separate the music from its dance context for learning or scrutinizing it, within the context of Candomble they blur one another. During an interview with Ogã Paraná, the inadequacy of such separation became clear. Enquired about his feelings while playing for the orixás, he replied:

That's something a bit hard to explain because we are there emanating right? We are like a shaman, that is, we make the trance take place, we make people fall in trance. And that's a connection, because one cannot separate the person playing from the rhythm; from what is being played. All that is a union, a linking point, so you are involved, once you are playing, you're involved with everything. But we are not [able of falling in] of trance. ${ }^{48}$ (Interview on $07.08 .2013^{49}$ )

\footnotetext{
47 "L'apprentissage des sons, l'entrée dans leur familiarité à travers leur integration dans un univers de sens, participe de la culture ambiante, du bain sonore qui imprègne l'enfant"

48 "Oh é uma coisa assim um pouco difícil de responder porque a gente está ali emanando né, a gente como é como um xamã, quer dizer, a gente faz com que o pessoal, que o transe venha, que caia em transe. E é uma ligação, porque não dá para separar a pessoa que está tocando com o ritmo né, com o que está sendo tocado. Aquilo é tudo uma união, um elo, então você está envolvido, você está tocando, você está envolvido com tudo né. Só que não somos de transe."
} 
Paraná illustrates the interweaving is not simply between the drummer and the dancer, but between "the person playing" and the "rhythm being played". Instead of separating subjects dancing and subjects playing music, he articulates the coherent whole of the Candomblé ritual, which goes far beyond dance, drums, singing and possession: "all that is a union, a bond". Similarly, Ogã Paraná had told us during that workshop that he first danced the rhythms before learning to play them. During childhood, he listened to the rhythms with his whole body, reproducing them in the form of footsteps and gestures, and only later translated them into their respective percussive forms. His example indicates that the inverse of the frequent statement that "dancing is listening" is also true: in Candomblé, listening is dancing.

Only after acknowledging the inextricability between music and dance, I was able to understand an important aspect conveyed in the following field note:

I focused my attention on the footsteps - since at the ritual one's feet do whatsoever for the impossibility of seeing them [due to the long skirts] - as well as on the feeling of the dance. At some point Murah even talked about it, saying that we should listen to the rhythm. Once again he talked about the connection between rhythm and dance, between the Ogã and the dance. He showed the difference between a "square" dance, a loose and joyful dance and the orixá dance, a ritualistic one with the feeling/rhythm of the orixá. (Field note from 09.02.2014)

What took me to associate the "feeling of the dance" with what "Murah talked about" when calling our attention towards the rhythm? And for what reason did I put a forward slash between "feeling" and "rhythm", suggesting their equivalence? My field notes were written without much editing. Consequently, what I wrote shortly after the experience described seemed self-evident to me at the moment of writing it down. It expressed something I already knew, but was not really aware of: the feeling of the dance is the rhythm and the rhythm is the orixá.

This becomes more evident through Murah's demonstration of a "lively and loose dance" - such as samba -, of a "square dance" - a dance with rigid body members and movements -, and of the ritual "orixá dance". Because the latter conveys, above all, Candomblé values, it must not be taken with seriousness, but seriously, i.e. with solemnity and respect for its sacredness. His first example of samba, in turn, refers to profane and casual dances, mostly performed for entertainment and uncommitted to the sacred. With the second example of square dances, Murah points out a contrast between too "vivid" and too "rigid" dances, for suggesting that Candomblé dances are in-between: neither loose, but unconstrained; nor rigid, but solemn; they shall incorporate the "orixá's feeling/rhythm". Body movements, musical rhythms and orixás feelings and meanings are modalities of one's experience.

At the workshop in February 2014, when we couldn't grasp Murah's demonstration of the connection between the drum and Xangô's movements, Joana Bahia, an observing anthropologist, asked him about the meaning behind a specific gesture. Xangô rolls his closed hands as if wrapping each other, every four beats one of them is uplifted while he turns the whole body for repeating it the sequence towards the other side: "at 
Xangô's dance one makes a turn around, and Joana [Bahia] asked what it meant, [Murah:] "it's the meteorite dance; Xangô brings the meteorite to Earth". (Field note from 09.02.2014)

Participants always received with Murah's enthusiastic explanations about what the dances actually represent, for their insightfulness in diverse levels. First, they provide hints to the symbolic meaning of the dance and to the orixá's mythology: that day we learned about a myth in which Xangô brings a meteorite from the sky to the Earth. Secondly, we might immediately involve the abstract movements we are learning with meanings that, among others, spatially locate our performance, and therefore they become gestures: our arms should not simply roll and move up and down; they should carry the meteorite.

Above all, Murah's verbal explanation informs us about the intentionality of the movements. He frequently employs metaphors having no direct correlation with the meanings communicated by the dance, which somehow enhances the "feeling" it is supposed to express. For improving our performance of Xangô's gesture of cutting with double hatchets, which no one was executing with the right height for shoulders, elbows and hands, he compared it simply to "shaking laundry". The moment he said it, we all immediately grasped and performed the expected feeling and gesture. We figured out the imposing force needed to achieve the intentionality of something never experienced, namely the use of two axes for cutting back and forward.

Whereas the unrelated metaphor of laundry led to the physical accuracy of the gesture, regardless of its actual meaning, the reference to the actual symbols embedded in the dances informs at once the physical, the symbolic and the emotional intention of the movement. Xangô carrying the meteorite to Earth involves more than drawing a descendent bow with one's arm: it is bringing the solidity of a giant meteor - one of Xangô's symbols - from an unreachable distance from up high until the floor, where it crashes and rolls. The dance is not a simple representation of this mythical scene, but re-enacts Xangô's thunderous power and strength; it re-enacts the intentionality, the essence of the orixás0, through a gesture:

The differentiation of various meaning aspects of gestures is highly important, and only by means of mimesis can the bodily representation and expression sides of a gesture be assimilated. The bodily processing of a gestural enactment takes place through mimesis and through a medium that differs from verbal communication. The specific character of bodily self-expression is captured by means of the mimetic perception of a gesture. In the "assimilation/imitation" of the gesture of the other, his corporeality and world of feelings are experienced. ${ }^{51}$ (WULF, 1997, p. 521, trans by author).

\footnotetext{
50 After writing these paragraphs on Xangô meteorite steps, I left the library and came across the German word "meteorite" on a huge program panel of Gorki Theater in Berlin. The whole program was written in white on a red background, Xangô's colours.

51 "So wichtig die Differenzierung unterschiedlicher Bedeutungsaspekte von Gesten ist, erst mit Hilfe der Mimesis kann die körperliche Darstellungs- und Ausdruckseite der Geste aufgenommen werden. Über die Mimesis der gestischen Inszenierung erfolgen deren körperliche Verarbeitung, die sich demgemäß in einem anderen Medium als dem der verbalen Kommunikation vollzieht. Über die mimetische Perzeption der Geste wird der spezifische Charakter des körperlichen Selbstausdrucks eines anderen Menschen erfaßt. In der "Anähnlichung" an die Gesten eines anderen werden seine Körperlichkeit und seine Gefühlswelt erfahren"
} 
Although Murah uses verbal communication for synthesizing diverse ineffable features of the gestures, they are always accompanied by his own emphatic gestures and facial expressions. In the case of the laundry metaphor, his words stressed one single aspect of the intentionality of his whole body expression. If the spatial positioning of our hands could even be accurate, it still lacked the proper "world of feelings" correspondent to the thunderous orixá of justice, Xangô. After seeing him performing the gesture with his whole body while drawing our attention through the metaphor towards its intentionality, we could imitate his performance and be able to sense and embody his as well as Xangô's "corporeality and world of feelings".

\section{"Singing with heart": literal and contextual meanings}

"The mouth talks about what the heart is full of" Babalorixá Muralesimbé52

After memorizing several melodies and lyrics, having them first "in the head", there were still several subtle nuances to be "polished". Beyond musical attributes, the literal meanings of cantigas are rarely taught in ilê. When Murah says that "it's better to sing nonsense" in a first moment, it does not mean that the lyrics content is irrelevant. Ogã Paraná, the only person to speak and still study Yoruba, often tests us while complaining about the scarcity of our knowledge of the language. He argues that "one must know what one is singing/saying" 53 , for one can be even spelling words mistakenly and attracting the wrong energies, for instance.

Knowing the literal - objective - meanings of cantigas, however, doesn't necessarily imply grasping their full significance, since in oral traditions they bear interdependency with the immediate context (cf. ONG, 2002, p. 42). Once we had a cantiga class in the presence of Dofono Louize, who taught us the following song:

There's a cantiga I like: "Yalode, Yalode ya oro, Yalode ya oro, yalode ya oro". The song says that Oxum is the mistress of society and she is the mistress of secrecy too. (Recorded cantigas class on 03.02.2014).

For the reader, Louize's translation probably does not convey much meaning, as it didn't to me that day also. After hearing it in diverse situations, however, I perceive this song as one of the most typical cantigas de Oxum. "Yalode ya oro" received a contextual signification to me. Nowadays I know, for instance, that Oxum is the mistress of the oracle's "secrecy"; she was the first orixá capable of consulting the jogo de búzios (cowry mussels' oracle), since Orumilá, the oracle orixá, gave her this power, according to myths. The "mistress of society" alludes, in turn, to Oxum's wealth and noblesse. From experience I know nowadays that the song is frequently played for Oxum for praising

\footnotetext{
52 "A boca fala do que tá cheio o coração", interview on 03.03.2014.

53 "Tem que saber o que se está cantando/falando!", frequent statement of Ogã Paraná.
} 
her especially at xirê, the public festival. With time I might realize a more functional role of the song within a ritual.

The importance of the cantigas content for the ritual was widely discussed during a cantigas class, when Ekédji Herica d'Ogum ${ }^{54}$ started to explain the meaning of a cantiga de lansã:

\begin{abstract}
Herica: This is a song we sing more at the end of xirê, because it's when, because she... There's a story... That's the xirê thing, you know? What I think we lack is having the knowledge of the... Because you invite the orixá to dance... Paulo: You have a plot, right?

$\mathrm{H}$ : Exactly, you call the orixá, he presents himself in the manners... you know? And this "zambele zambele mixaxe" is where she shows herself, she [the goddess lansã] will wash herself in the waters, she is cleaning herself. I get goose bumps when I talk about this... You know? Because this is what we should feel, it's what lacks between us and the orixá and this knowledge... It's this...

P: Understanding of the plot, right?

$\mathrm{H}$ : This understanding and knowing what you are singing and in which moment you sing it. For instance, she says "é koro ô"; she is saving the head of the house's children, hers and the house's children, so we must know why she is singing that at that moment. It is something we lack, it remains without heart, it remains a song sung repeatedly, because you've learned it, but you don't know what is behind the cantiga - this is lacking and I find it a pity to memorize something while not knowing what one is singing, unfortunately. ${ }^{55}$ (Cantigas class on 04.11.2013, my emphasis)
\end{abstract}

Ekédji Herica was not merely claiming for the regular transmission of the lyrics' content; otherwise she would have conveyed the literal translation of "zambele mixaxe" and "é koro o" straight ahead. Instead, she was stating the value of what is "behind the cantiga", of all the content and experiences that words only synthetically refer to but cannot objectively convey: their symbology, "what" one is singing; their ritual context, "in which moment" one sings; and the emotions evoked by such interrelatedness, such as Herica's immediate goose bumps. Without this sensuous knowledge, a cantiga is a "song sung repeatedly": an automatism lacking the emotions evoked, a repetition without meaning, "without heart".

Being able to recall a melody "by heart" differs from knowing a song "with heart". Latter implies knowing what lies in its heart, or, following Merleau-Ponty, its "emotional essence":

\footnotetext{
54 Brazilian woman (+50) from Ribeirão Preto, São Paulo. Ekédjis are female practitioners with special tasks, who, like male ogãs, cannot fall in trance.

55 "Herica: é uma cantiga que a gente canta mais pro finalzinho do xirê, porque é quando, porque ela... tem uma hist... Esse que é o lance do xirê, sabe assim, que eu acho que fica faltando, a gente ter o conhecimento desse... Porque você convida o orixá pra dançar... - Paulo: Você tem um enredo, né? - H: Exatamente, você chama o orixá, ele se apresenta das maneiras... Entendeu? E esse "zambele zambele mixaxê" é onde ela se mostra, que ela vai se lavar nas águas, "zambele zambele mixaxê", e ela faz esse movimento aqui porque ela tá se lavando, entendeu, ela tá se limpando. Eu fico arrepiada quando eu falo dessa... Sabe? Porque é isso que a gente tem que sentir, é o que falta com a gente e o orixá e o co... É essa... - P: Entendimento do enredo, né? - H: Esse entendimento e você saber o que você tá cantando e em que momento você canta. Por exemplo, ela fala "é koro ô", ela tá salvando a cabeça dos filhos da casa, dela e dos filhos da casa, então a gente tem que saber por que é que ela tá cantando aquilo naquele momento, é uma coisa que falta pra gente, fica sem coração, fica uma cantiga cantada repetida, porque você aprendeu, mas você não conhece o que leva atrás da cantiga, o que falta; eu acho uma judiação. A gente decorar uma coisa e depois não saber o que tá cantando, infelizmente."
} 
It would then be found that the words, vowels and phonemes are so many ways of 'singing' the world, and that their function is to represent things not, as the naïve onomatopoeic theory had it, by reason of an objective resemblance, but because they extract, and literally express, their emotional essence. (MERLEAU-PONTY, 2005 p. 236, my emphasis)

That day, I learned to touch my head while we sing "é koro o", which became an automatic gesture accompanying the song, and, still, I do not associate it with all the meanings informed by Ekédji Herica. My only association is the emotion that the performance of this refined gesture triggers, which strengthens the trust that the orixá will protect my head.

The discussion went on:

\begin{abstract}
Iris: I've written what it means, what we are singing here. For "zambele zambele mixaxê" I've written "lansã floats with the wind" [...]

Herica: [...] When lansã dances to this song...

I: Don't touch her!

$\mathrm{H}$ : And sings it, please don't touch her, don't come close to her, because she is carrying nine eguns (spirits of deceased), nine spirits under her skirt; she is protecting them. And when she sings, she shows it by uplifting her skirt, you know? So one should touch neither her nor her skirt and should preferably let her dance alone, ok? [...] Did you understand why we should know it? It's because that's what makes up the knowledge of the whole thing. ${ }^{56}$ (Recorded cantigas class on 04.11.2013, my emphasis).
\end{abstract}

With this, Herica gave an example of why one "must know what one is singing", as to avoid the danger of dealing with the wrong energies - wrong meanings. Someone unaware of the myth behind these lyrics might touch lansã and the dead spirits she carries under her skirt at this moment. Although the lyrics only communicate, according to Iris, "lansã floats with the wind", lansã moving her skirt while dancing represents further significations implicit in her mythology and emotional essence.

The statement, "this is what makes up the knowledge", corresponds to what Murah once expressed while reprehending Vera for ignoring the name of the dish she was preparing: "one has to know what he is doing and what for"57. In that case, Vera did know how to cook the dish in question, which accomplished its ritual function several times, but not its name. In the same way, regardless of members' unawareness of the literal content of lyrics, the songs usually accomplish their ritual function of increasing axé, as Ekédji Herica further mentioned:

Herica: Because we must know what it is about, why we sing the song in this moment, so that it becomes linked... I don't know... with a feeling. Otherwise it's simply an automatic repetition and we don't know what it is about. Of course one can sense the energy [axé], one is not dumb. That's not the case. The energy is there and you receive it. But it would be better if...

\footnotetext{
56 "Você entendeu que a gente deveria saber? Porque é o que faz o conhecimento da coisa."

$57 \quad$ Field note from 22.01.2014.
} 
Vera: The story...

Iris: The stories are there! ${ }^{58}$ (Cantigas class on 04.11.2013).

Everyone at the discussion was sharing an "anxiety of knowing", as put later by Ogã Paulo: it was hard enough for him as well as for other members to solely learn the songs "without heart"; to be capable of simply "automatically repeating" them. Ekédji Herica, even though being able to "repeat" several cantigas, was expressing her anxiety of not knowing enough about their complex meanings and the feelings linked to them, while stating that this knowledge has a fundamental value in Candomblé. Vera and Iris complete what Herica was trying to communicate, that "the stories" are inside songs, movements, feelings. Herica's stating that this is what makes the knowledge of the whole thing corresponds to Polanyi's "Comprehensive entity" of tacit knowledge, in opposition to the "automatic repetition" of songs:

Scrutinize closely the particulars of a comprehensive entity and their meaning is effaced, our conception of the entity is destroyed. [...] Repeat a word several times, attending carefully to the motion of your tongue and lips, and to the sound you make, and soon the word will sound hollow and eventually lose its meaning. [...] Admittedly, the destruction can be made good by interiorizing the particulars once more. The word uttered again in its proper context [...]" comes "to life and recover" its "meaning and [...] comprehensive relationship". (POLANYI, 1966, p. 18-19).

Experience brings gradually the intersection of Polanyi's "particulars". It enables us to associate both consciously and unconsciously cantigas, dances, mythology, colours, and events, which are called significations, with the emotions they evoke, and with the energy and the axé they bring forth; this is called their sensibility. "The stories are there", within the songs, the orixás' myths, accomplishments and characteristics, their symbols are conveyed in the songs, as much as in the dances, the rhythms, the dishes, etc. Learning Candomblé songs involves much more than memorizing melodies and lyrics towards an "automatic repetition" or a song "without heart"; it means apprehending Candomblé, that is, getting to know and feel the orixás while perceiving and acquiring axé. This demands a contextual knowledge that only intense and repeated practice can transmit. Time and practice renders songs into chants, signs into feelings; it renders a "junction of sensitivity and significance" revealing "the existential conditioning of both" (MERLEAU-PONTY, 2005, p. 151).

\section{Conclusions}

In my Candomblé apprenticeship, to sing and dance gradually ceased to be an attempt of "objectively resembling" choreographic and sonorous representations, turning

\footnotetext{
58 "Herica: Weil wir müssen wissen, worum es geht, warum wir in diesem Moment dieses Lied singen, damit es auch mit... ich weiss es nicht, verbunden mit einem... Einem Gefühl. Es ist einfach eine automatische Wiederholung und wir wissen nicht, worum es geht. Man merkt natürlich die Energie [axé], man ist ja nicht doof. Das ist ja nicht. Die Energie ist da, man kriegt es auch mit. Aber das wäre schon... - Vera: Die Geschichte... - Iris: Die Geschichten sind da!"
} 
into "ways of singing the world" of and for the orixás. If to utter "kawo kabiesile"59 was first the repetition of Yoruba phonemes of which literal meaning I ignored, or shaking both arms back and forward hand was first an abstract dance movement, they came to mean much more than the representation of a greeting or of two axes. Nowadays, they carry "magical potency", they express the emotional essence of Xangô arising from the amalgamation of diverse ritual, choreographic, musical, collective experiences gathered throughout five years practicing Candomblé.

So when one knows what one's dancing, he's accompanying the whole story that he's singing; he's accompanying all that rhythm being played. Thus, it's that rhythm, the dance form and the cantiga that make, that bring axé; that bring the energy for incorporation. ${ }^{60}$ (Babalorixá Muralesimbé, interview on 03.03.2013)

It is precisely the interweaving of the particulars - stories, cantigas, rhythms, dance forms - that renders possible the ultimate embodiment of Candomblé: producing and perceiving axé to the point of the orixá's incorporation. But first one must know the particulars, "know what one is doing" and "dancing", in order to gradually perceive their interaction. The fundamental value to be learned, transmitted and shared in the religion is the power of the orixás: how to both individually and collectively sense, make sense of, and increase axé.

We first learn to move the body without knowing the intentions of the movement; to "suspend an arm in front of the face" without knowing that one is imaginatively holding a mirror, or that this gesture symbolizes Oxum's vanity and joyfulness. We sing "songs without heart" in order to later embody their "hearts", their meanings and feelings; the emotional essence of such a sensuous knowledge. With time, we embody their literal meanings, their meanings within context and their sensed meanings - to be discussed in a further article.

Ossaim, the orixá of sacred herbs and enchantment is both male and female, both human and the flora. Ossaim seems to embody mimesis; a conscious and unconscious, rational and sensuous, objective and subjective, endeavour. Candomblés apprehension is only fully achieved by collectively engaging the body in it. Melodies, gestures, lyrics meanings remain empty, "without heart", if only repeatedly and abstractly learned, apart from their ritual context. Once learned within their contextual setting, their inextricability not only becomes evident, but embodied: to sing and dance for the orixá is to hear his music and to move within his myths. The practitioner doesn't simply imitate representations, nor deciphers and grasps abstract meanings and metaphors. Instead, he senses those meanings with his whole body and assimilates their essence; he "makes sense" of them (cf. BOURDIEU, 1980, p. 62). "What one learns with the body is not something one has, like a knowledge he can hold in front of himself, but something one is" (BOURDIEU,

\footnotetext{
59 Oxóssi's greeting.

60 "Então quando ele sabe o que ele tá dançando, ele tá acompanhando a história que ele tá cantando. Ele tá acompanhando todo aquele ritmo que tá se tocando. Então aquele ritmo, a forma de dançar e a cantiga que faz, que traz o axé, que traz a energia que vai fazer a incorporação".
} 
1980, p. 123, trans. by author). In Candomblé, one doesn't simply learn about, but learns the orixás by feeling their meanings within his own body.

When singing transcends the memorization of lyrics and melodies by engaging the body, senses and the self, it becomes chanting. When the same engagement turns the art of moving the body into performing the orixás, one learns the orixá. By perceiving several meanings of the orixá with one's body resonating with the bodies of others, one senses the power of the sensuous knowledge, of the wisdom, acquired. Those meanings make sense and take effect: embodiment is achieved; the body got enchanted.

\section{Bibliographic references}

AGAWU, V. Kofi. The Rhythmic Structure of West African Music. In: The Journal of Musicology 5/3, 1987. p. 400-418.

ANJOS, José Carlos Gomes do. A filosofia política da religiosidade afro-brasileira como patrimônio cultural africano. Debates do NER 9/13, 2008. p. 77-96.

BASTIDE, Roger. Le candomblé de Bahia (rite nagô). Paris: La Haye, 1958.

As Religiões Africanas no Brasil. São Paulo: Pioneira, 1971 [1960].

BERGER, Peter L., and Thomas LUCKMANN. The Social Construction of Reality: a treatise in the sociology of knowledge. New York: Anchor books, 1967.

BLACKING, John. Music, Culture, and Experience: Selected Papers of John Blacking. Chicago and London: University of Chicago Press, 1995.

BOURDIEU, Pierre. Esquisse d'une Théorie de la Pratique: précédé de trois études d'ethnologie kabyle. Genève: Droz, 1972. Le Sens Pratique. Paris: Éditions de Minuit, 1980.

BRETON, David le. La Saveur du Monde: une anthropologie des sens. Paris: Éd. Métailié, 2006.

traitements, 4/96: p. 45-53, 2007.

BUTLER, Judith. Performative Acts and Gender Constitution: an essay in 
phenomenology and feminist theory. In: Theatre Journal 40/4, 1988. p. 519-531.

CHERNOFF, John Miller. African Rhythm and African Sensibility. Chicago: The University of Chicago Press, 1978.

CONQUERGOOD, Dwight. Rethinking Ethnography. Towards a Critical Cultural Politics. Communication Monographs 58, 1991. p. 179-194.

Performance Studies: interventions and radical research.

The Drama Review 46/2, 2002. p. 145-156.

CONNERTON, Paul. How Societies Remember. Cambridge, New York: Cambridge University Press, 1989.

COSSARD, Gisèle Omindarewá. Awô. O mistério dos orixás. Rio de Janeiro: Pallas, 2008.

CSIKSZENTMIHALYI, Mihaly. The Flow Experience and Its Significance for Human Psychology. In: Optimal Experience: psychological studies of flow in consciousness, edited by Mihaly Csikszentmihalyi and Isabella S. Csikszentmihalyi. Cambridge: Cambridge University Press, 1988. p. 15-35.

CSORDAS, Thomas. Embodiment as Paradigm for Anthropology. In: Ethos 18/1, 1990. p. 5-47.

Somatic Modes of Attention. In: Cultural Anthropology 8/2,

1993. p. $135-156$.

DESMOND, Jane C. Embodying Difference: issues in dance and cultural studies. In: Cultural Critique 26, 1993. p. 33-63.

FABIAN, Johannes. Power and Performance: Ethnographic Explorations through Proverbial Wisdom and Theatre in Shaba, Zaire. Madison: The Univeristy of Wisconsin Press, 1990.

GEBAUER, Gunter; WULF, Christoph. Mimesis: Kultur - Kunst - Gesellschaft. Reinbek bei Hamburg: Rowohlt, 1992.

GOLDMAN, Marcio. Formas do Saber e Modos do Ser Observações Sobre Multiplicidade e Ontologia no Candomblé. In: Religião e Sociedade 25 (2), 2005. p. 102-120. 
Histórias, devires e fetiches das religiões afro-brasileiras. In:

Análise Social, vol. XLIV (190), 2009. p. 105-137.

GRAEFF, Nina. "Experiencing Music and Intangible Cultural Heritage: Some Thoughts on Safeguarding Music's Intangible Dimension". In: El oído pensante 2 (2), 2013. p. 1-21. http://ppct.caicyt.gov.ar/index.php/oidopensante

Ich werde mein Orixá. Mimetische Prozesse in der Weitergabe des

Candomblé in Berlin. In: Paragrana 23/2, 2014a. p. 216-228.

Transmitiendo y preservando lo ,inmaterial' en una casa de candomblé en Berlín. In: Ensayos: Historia y Teoría del Arte 25/17, 2014b. p. 23-37.

Fundamentos Rítmicos Africanos para a Pesquisa da Música AfroBrasileira: o exemplo do Samba de Roda. In: Música e Cultura 9, 2014c. p. 1-23.

Os ritmos da roda. Tradição e transformação no samba de roda.

Salvador: EDUFBA, 2015a.

Embodying Candomblé Dances, Safeguarding Intangible Heritage.

In: Dance, narratives, heritage: 28th symposium of the ICTM Study Group on

Ethnochoreology: Zagreb, Croatia: Institute of Ethnology and Folklore Research; ICTM Study Group on Ethnochoreology, 2015b. p. 280-285.

. Oxum's mirror: Embodying Candomblé Transculturally. Ph.D. thesis.

Free University of Berlin, November 2016.

HAZZARD-GORDON, Katrina. Afro-American Core Culture Social Dance: an examination of four aspects of meaning. In: Dance Research Journal 15/2, 1983. p. 2126.

KIRSHENBLATT-GIMBLETT, Barbara. Destination Culture. Tourism, Museums, and Heritage. Berkeley: University of California Press, 1998.

KUBIK, Gerhard. Zum Verstehen afrikanischer Musik. Leipzig: Philipp Reclam, 1988.

KUBIK, Gerhard. Kognitive Grundlagen afrikanischer Musik. In: Musik in Afrika: Mit 20 Beiträgen zur Kenntnis traditioneller afrikanischer Musikkulturen, edited by Artur Simon. Berlin: Museum für Völkerkunde, 1983. p. 327-400.

LAVE, Jean; WENGER, Etienne. Situated Learning. legitimate peripheral participation.

Cambridge, New York: Cambridge University Press, 1991. 
MALINOWSKI, Bronislaw. Argonauts of the Western Pacific. An account of native enterprise and adventure in the archipelagoes of Melanesian New Guinea. New York: Dutton, 1922.

MAUSS, Marcel. Anthropologie et Sociologie. Paris: PUF, 1950.

MERLEAU-PONTY, Maurice. Phenomenology of Perception. Trans. by Colin Smith. Routledge: London \& New York, 2005 [1945].

ONG, Walter J. Orality and Literacy: the technologizing of the World. Routledge: London \& New York. 2002 [1989].

PELINSKI, Ramón. "Embodiment and Musical Experience". In: TRANS 9 (December 2005). http://www.sibetrans.com/trans/articulo/178/embodiment-and-musicalexperience [Accessed 19th November 2018].

PINTO, Tiago de Oliveira. Capoeira, Samba, Candomblé: Afro-brasilianische Musik im Recôncavo, Bahia. Berlin: Museum für Völkerkunde, 1991.

POLANYI, Michael. The Tacit Dimension. London: Routledge \& Paul, 1966.

RODRIGUES, R. Nina. L'animisme fétichiste des nègres de Bahia. Salvador: Reis, 1900.

ROSA, Hartmut. Resonanz: Eine Soziologie der Weltbeziehung. Berlin: Suhrkamp, 2016.

RYLE, Gilbert. The Concept of Mind. London, New York: Routledge, 2009 [1949].

SANTOS, Boaventura de Sousa. Beyond Abyssal Thinking: from global lines to ecologies of knowledges. Revista Crítica de Ciencias Sociais 30 (1), 2007. p. 45-89.

TAYLOR, Diana. The Archive and the Repertoire: cultural memory and performance in the Americas. Durham, London: Duke University Press, 2003.

Performance and Intangible Cultural Heritage. In: The Cambridge Companion to Performance Studies, edited by Tracy C. Davis. Cambridge: Cambridge University Press, 2008. p. 91-104.

WACQUANT, Loïc. Corps et Âme. Carnets ethnographiques d'un apprenti boxeur. Marseille: Agone, 2000.

WELSCH, Wolfgang. "Transculturality - the Puzzling Form of Cultures Today". In Spaces of Culture: city, nation, world, edited by M. Featherstone and S. Lash. London: Sage, 
1999. p. 194-213.

WULF, Christoph. Gesten. In: Vom Menschen. Handbuch Historische Anthropologie, edited by Christoph Wulf. Weinheim; Basel: Beltz, 1997.

Anthropologische Dimensionen des Tanzes. In: Tanz als

Anthropologie, edited by Gabriele Brandstetter and Christoph Wulf. Munich: Wilhelm Fink, 2007. p. 121-31. 